\title{
Chickenpox pneumonia: experience with antiviral treatment
}

\author{
R N DAVIDSON, W LYNN, P SAVAGE, M H WANSBROUGH-JONES \\ From the Department of Communicable Diseases and Radiology, St George's Hospital, London
}

ABSTRACT Of 13 patients with chickenpox pneumonia (12 of them adults) treated during 1979-87, 10 received antiviral drugs-nine acyclovir and one vidarabine. Three died despite intensive treatment. Serious secondary infections occurred in six cases. There were no clear indications that antiviral treatment altered the natural history of the condition. Acyclovir may at present be used too late in the course of chickenpox pneumonia to alter its outcome.

\section{Introduction}

Chickenpox pneumonia, first described in $1942,{ }^{1}$ can be severe or even fatal in previously healthy individuals. ${ }^{2-8}$ Estimates of its incidence vary, the highest being half of all adult cases of chickenpox. ${ }^{5} \mathrm{~A}$ study of United States military personnel found radiographic changes in $16 \%$ of adult patients, of whom only a third had symptoms. ${ }^{6}$ Other authors report an incidence of pneumonia of $16.5 \%{ }^{3}$ and $14 \% 5$ of adult cases, with a far higher incidence in pregnant women. ${ }^{5}$ In children the incidence of pneumonia has ranged from $0.8 \%$ to $14 \% .{ }^{910}$ Malignant disease and cytotoxic and steroid treatment are predisposing factors. " Published case reports ${ }^{12-17}$ suggest that antiviral treatment is beneficial. The onset of respiratory symptoms, however, is often late and, as the efficacy of antiviral drugs for varicella-zoster virus infections is related to the time at which treatment is started, we may reasonably doubt whether antiviral drugs would be of benefit.

During 1985 five patients with chickenpox pneumonia in adults were seen by our regional communicable diseases unit. Review of the records showed that five cases had occurred in the previous six years, and since then two cases in 1986 and one in 1987. This experience has prompted a review of the clinical, laboratory, and radiological features of chickenpox pneumonia since antiviral treatment became available.

Address for reprint requests: $\operatorname{Dr} M \quad H$ Wansbrough-Jones, Department of Communicable Diseases, St George's Hospital Medical School, London SW17 0RE.

Accepted 11 May 1988

\section{Methods}

The patients were admitted to the regional communicable disease unit at St George's Hospital from 1979 to 1987. Most were referred from within Wandsworth Health District (population 290000 ). The diagnosis of chickenpox was not in doubt clinically and in all patients either there was a contact history or varicella-zoster virus was identified directly (five patients) or on the basis of a significant rise in specific antibody titre. Case notes were reviewed to obtain information on clinical features, results of laboratory investigations, treatment, and outcome.

\section{Results}

Details of the patients are given in the table. Ten patients complained of cough or breathlessness and five produced small amounts of blood stained sputum. Five patients had chest pain and most had discomfort over the trachea. Vesicles were present on the palate of all patients and lesions were seen in the larynx and trachea during intubation of patient 6 . In patients 7 and 9 respiratory symptoms preceded the appearance of a rash by a day, whereas the rash preceded respiratory symptoms by two to five days in the remaining patients. Signs of pneumonia were confined to tachypnoea and sparse fine inspiratory crackles at the lower zones.

Two patients may have had altered immunity. Patient 3 had received a bone marrow transplant two and a half years earlier for aplastic anaemia. She had been regarded as immunologically normal before her fatal illness and she was not receiving immunosuppressive drugs. Sarcoidosis had been diagnosed 
Timing of events, treatment, and outcome in 13 patients with chickenpox pneumonia

\begin{tabular}{|c|c|c|c|c|c|c|c|c|c|}
\hline $\begin{array}{l}\text { Patient } \\
\text { No }\end{array}$ & Age, sex & Smoker & $\begin{array}{l}\text { Onset of } \\
\text { respiratory } \\
\text { symptoms (days } \\
\text { after rash } \\
\text { started)* }\end{array}$ & $\begin{array}{l}\text { Antiviral } \\
\text { treatment }\end{array}$ & $\begin{array}{l}\text { Duration of } \\
\text { rash (days) } \\
\text { before } \\
\text { drug started }\end{array}$ & $\begin{array}{l}\text { Days in } \\
\text { hospital }\end{array}$ & $\begin{array}{l}\text { Days of } \\
I P P V\end{array}$ & Outcome & $\begin{array}{l}\text { Other } \\
\text { conditions }\end{array}$ \\
\hline $\begin{array}{l}1 \\
2 \\
3\end{array}$ & $\begin{array}{l}37, \mathrm{M} \\
31, \mathrm{~F} \\
14, \mathrm{~F}\end{array}$ & $\begin{array}{l}\text { Yes } \\
\text { Yes } \\
\text { No }\end{array}$ & $\begin{array}{l}? \\
2 \\
5\end{array}$ & $\begin{array}{l}\text { ARA-A } \\
\text { None } \\
\text { ACV }\end{array}$ & $\begin{array}{l}? \\
5\end{array}$ & $\begin{array}{l}9 \\
5 \\
2\end{array}$ & $\begin{array}{l}0 \\
0 \\
1\end{array}$ & $\begin{array}{l}\mathbf{R} \\
\mathbf{R} \\
\mathbf{D}\end{array}$ & $\begin{array}{l}\text { Sarcoidosis } \\
\text { Multiple sclerosis } \\
\text { Bone marrow } \\
\text { transplant }\end{array}$ \\
\hline $\begin{array}{r}4 \\
5 \\
6 \\
7 \\
8 \\
9 \\
10 \\
11\end{array}$ & $\begin{array}{l}\text { 39, M } \\
29, \mathrm{~F} \\
47, \mathrm{M} \\
39, \mathrm{M} \\
27, \mathrm{M} \\
36, \mathrm{~F} \\
29, \mathrm{M} \\
48, \mathrm{M}\end{array}$ & $\begin{array}{l}\text { Yes } \\
\text { Yes } \\
\text { Yes } \\
\text { Yes } \\
\text { Yes } \\
\text { Yes } \\
\text { No } \\
\text { Yes }\end{array}$ & $\begin{array}{l}4 \\
3 \\
3 \\
-1 \\
2 \\
-1 \\
3 \\
4\end{array}$ & $\begin{array}{l}\text { None } \\
\text { ACV } \\
\text { ACV } \\
\text { ACV } \\
\text { ACV } \\
\text { ACV } \\
\text { None } \\
\text { ACV }\end{array}$ & $\begin{array}{l}5 \\
7 \\
2 \\
2 \\
4 \\
5\end{array}$ & $\begin{array}{r}4 \\
8 \\
3 \\
16 \\
23 \\
13 \\
6 \\
15\end{array}$ & $\begin{array}{r}0 \\
0 \\
2 \\
0 \\
11 \\
5 \\
0 \\
14\end{array}$ & $\begin{array}{l}\mathbf{R} \\
\mathbf{R} \\
\mathbf{D} \\
\mathbf{R} \\
\mathbf{R} \\
\mathbf{R} \\
\mathbf{R} \\
\mathbf{D}\end{array}$ & $\begin{array}{l}\text { Encephalitis, hepat } \\
\text { Hepatitis B virus ca }\end{array}$ \\
\hline $\begin{array}{l}12 \\
13\end{array}$ & $\begin{array}{l}39, \mathbf{F} \\
31, \mathbf{M}\end{array}$ & $\begin{array}{l}\text { Yes } \\
\text { Yes }\end{array}$ & $\begin{array}{l}2 \\
3\end{array}$ & $\begin{array}{l}\text { ACV } \\
\text { ACV }\end{array}$ & $\begin{array}{l}6 \\
3\end{array}$ & $\begin{array}{l}13 \\
35\end{array}$ & $\begin{array}{r}0 \\
30\end{array}$ & $\begin{array}{l}\mathbf{R} \\
\mathbf{R}\end{array}$ & \\
\hline
\end{tabular}

* Minus sign indicates that respiratory symptoms preceded rash.

IPPV - intermittent positive pressure ventilation; ARA-A-vidarabine; ACV-acyclovir; $R$-recovered; D-died.

two years earlier in patient 1 ; when he developed chickenpox he had mild sarcoidosis not requiring treatment. Patient 2 had mild multiple sclerosis, and patient 8 was a chronic carrier of hepatitis $B$ virus positive for "e" antigen but with normal liver function; neither was receiving immunosuppressive drugs. Five patients were not of British origin-Nos 1 (Jamaican), 6 (Sri Lankan), 4 and 12 (Indian), and 13 (Anglo-Indian). Eleven patients smoked, and the mean cigarette consumption was 20 a day.

\section{RADIOGRA PHIC FINDINGS}

All patients had radiographic abnormalities on admission to hospital and these were greater than would have been predicted from physical examination of the chest. The most consistent feature was pulmonary nodules $2-10 \mathrm{~mm}$ in diameter, of soft tissue density. The initial pattern of diffuse fine nodular shadowing progressed with increasing size of the nodules to coalescence and areas of consolidation (figure). The maximum radiographic changes did not correlate well with the severity of the illness. Most patients showed extensive lung disease at some stage with relative apical sparing. Basal sparing was seen less commonly, and areas of consolidation seemed to be equally common in all lobes. Six patients had a pleural effusion, usually transiently. In five this was unilateral (four left sided) and in one (patient 8) bilateral.

\section{BIOCHEMICAL FINDINGS}

Ten patients were hyponatraemic on admission, including the three who died (mean plasma sodium concentration 131, range $125-134 \mathrm{mmol} / \mathrm{l}$ (normal $135-145 \mathrm{mmol} / \mathrm{l})$.

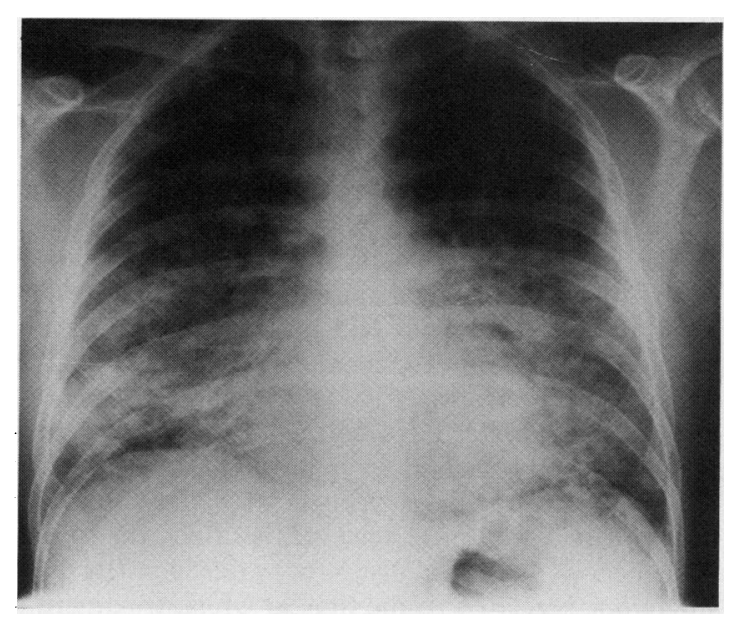

Patient 7: Radiograph taken on admission to hospital showing widespread nodular shadowing up to $10 \mathrm{~mm}$ in diameter; there is confluent consolidation in the right lower zone and a left pleural effusion, and the hilar markings are obscured bilaterally.

\section{BACTERIOLOGICAL FINDINGS}

Secondary bacterial infection may have occurred in six patients. Staphylococcus aureus was isolated from sputum in one case; from the tip of a venous canula in another; and from skin swabs, sputum, blood cultures, and the tip of a venous canula in a third. Staphylococcus epidermidis was grown from blood cultures in two patients, one of whom (No 11) also had Aspergillus sp in blood and sputum. Haemophilus influenzae was isolated from the sputum of the remaining patient. 


\section{LUNG FUNCTION}

Respiratory function tests had been performed fortuitously in patients 1,7 , and 8 before the chickenpox pneumonia. After their illness these patients showed a reduction in carbon monoxide transfer factor, which gradually returned towards normal over several months.

\section{TREATMENT AND OUTCOME}

Ten patients received an antiviral drug 2-7 days after onset of the rash, and 0-4 days after the onset of respiratory symptoms (table). One patient (No 1) received vidarabine $600 \mathrm{mg}$ daily for seven days. The other nine received acyclovir $10 \mathrm{mg} / \mathrm{kg}$ body mass eight hourly intravenously with a reduced dose where there was renal impairment. Patient No 3 died on the second day and No 6 on the third day after starting acyclovir treatment; the remaining patients received a five day course. The three patients who died had received acyclovir on days 5,5 , and 7 of the rash.

\section{Discussion}

There have been no controlled trials of antiviral agents in chickenpox pneumonia. The choice of drug relies therefore on case reports of adults with chickenpox pneumonia ${ }^{12-18}$ and on trials of treatment for cutaneous or visceral varicella in immunocompromised patients. ${ }^{1920}$ Claims for efficacy in varicella pneumonia have been made for transfer factor, ${ }^{21} \alpha$ interferon, ${ }^{15}$ vidarabine, ${ }^{1216}$ and acylovir. ${ }^{131718}$ Acyclovir, the drug of choice in other serious varicella-zoster virus infections, may be ineffective once visceral dissemination has occurred. ${ }^{20}$ Steroids are contraindicated ${ }^{11}$ except in cases of acute adrenal failure. ${ }^{22}$ The cases reported before antiviral agents were available clearly document the swift recovery of some patients. Thus single case reports of rapid improvement are not necessarily an indication of drug efficacy. Our experience suggests little departure from the natural history of this condition, possibly because treatment was started too late. Our three patients who died had not received an antiviral drug until at least five days after the onset of the rash (table), possibly because the cause of the respiratory symptoms was not recognised immediately.

The mortality rate for varicella pneumonia has been estimated at $10-30 \%,{ }^{8}$ although the incidental finding of calcification typical of previous varicella pneumonia in adult chest radiographs suggests that many cases may be unrecognised. Mortality statistics for England and Wales record around 19 deaths from chickenpox each year, a figure that remained fairly constant from 1967 to $1985,{ }^{23}$ the period when antiviral drugs were being introduced. Controlled trials in chickenpox pneumonia are difficult in view of the rarity of the condition, but a controlled trial of treatment of adults with chickenpox, using high dose oral acyclovir ( $800 \mathrm{mg}$ five times a day), could provide valuable information. Alternatively, all adults who develop chickenpox could have an early chest radiograph and any abnormality could be taken as an indication for starting antiviral treatment. Zoster immune globulin is effective in preventing or ameliorating chickenpox in susceptible children ${ }^{24}{ }^{25}$ but it is in short supply. ${ }^{25}$ The development of monoclonal antivaricella globulin ${ }^{26}$ allows the production of large quantities of material, which could also be subjected to clinical trial.

Prevention might be a better approach, and a live attenuated vaccine was developed in Japan in 1974. ${ }^{27}$ Despite early controversy, ${ }^{28}$ assessment of the vaccine has shown it to be safe and effective. ${ }^{30}$ It would be difficult, however, to identify susceptible adults at an acceptable cost.

We cannot explain our cluster of cases in 1985. Infectious diseases units in other parts of the country did not report a similar increase, although one unit reported a "cluster" during 1984 . Neither chickenpox nor chickenpox pneumonia is a notifiable disease, but the prevalence of chickenpox as estimated by the Royal College of General Practitioners was not unusually high (Public Health Laboratory Service Communicable Disease Report 86/06, unpublished) and schools in our locality did not report an increased number of infections.

Smoking may be a risk factor for the development of pneumonia ${ }^{18}$; of our two non-smokers, one had received a bone marrow transplant and the other (patient 10) had the mildest disease. Mean cigarette consumption was 26 a day in patients who needed intermittent positive pressure ventilation, compared with 18 a day in those who did not. Smoking renders human alveolar macrophages more susceptible to infection by herpes viruses, ${ }^{31}$ and this may have pathogenetic significance.

Studies of respiratory function abnormalities during and after chickenpox pneumonia have shown a reduction in carbon monoxide transfer coefficient (KCO) and steady state carbon monoxide diffusing capacity or transfer factor (TLCO), which may persist for years after the illness. ${ }^{32}$ Subclinical chickenpox pneumonia may also lead to a fall in Kco in smokers despite a normal chest radiograph. ${ }^{18}$

Regular samples should be taken of skin flora, blood, sputum, and urine for culture to identify secondary infections. The isolation of Staphylococcus epidermidis in blood cultures may be due to contamination, and isolation of Haemophilus influenzae and Staphylococcus aureus from sputum may be due to colonisation rather than infection. These organisms 
may become invasive through the inflamed skin, however, or via intravenous cannulas, endotracheal tubes, or urinary catheters.

The severity of chickenpox in adults may have been underestimated recently and there is a strong case for a reassessment of the strategy for antiviral treatment in these patients. Probably the best approach would be a trial of high dose oral acyclovir treatment in adults who develop chickenpox.

\section{References}

1 Waring JJ, Neubuerger K, Geever EF. Severe form of chickenpox in adults. Arch Intern Med 1942;69: 384-408.

2 Hampton AG Jr. Primary varicella pneumonia. Arch Intern Med 1955;95:137-40.

3 Weinstein L, Meade RH. Respiratory manifestations of chickenpox. Arch Intern Med 1956;98:91-9.

4 Krugman S, Goodrich CH, Ward R. Primary varicella pneumonia. N Engl J Med 1957;257:843-8.

5 Mermelstein RH, Freireich AW. Varicella pneumonia. Ann Intern Med 1961;55:456-63.

6 Weber DM, Pellecchia JA. Varicella pneumonia. JAMA 1965;192:572-3.

$7 \mathrm{Knyvett}$ AF. The pulmonary lesions of chickenpox. $\mathrm{OJ}$ Med 1966;35:313-23.

8 Triebwasser JH, Harris RE, Bryant RE, Rhoades ER. Varicella pneumonia in adults. Medicine (Baltimore) 1967;46:409-23.

9 Bullowa JGM, Wishik SM. Complications of varicella. Am J Dis Child 1939;49:923-32.

10 Neisenbaum C, Wallis K, Herczeg E. Varicella pneumonia in children. Helv Paediatr Acta 1969; 2:212-8.

11 Gershon AA. Steroid therapy and varicella. J Paediatr 1972;81:1034.

12 Teare EL, Cohen JA. Treatment of chickenpox pneumonia with adenine arabinoside. Lancet 1979; i:873.

13 Van der Meer JWM, Thompson J, Tan WD, Versteeg J. Treatment of chickenpox pneumonia with acyclovir. Lancet 1980;ii:473-4.

14 Brier A, Potgieter PD, Moodie J. Acyclovir and varicella pneumonia. S Afr Med J 1984;66:515.
15 Arvin AM. Human leukocyte (alpha) interferon of use in varicella? N Engl J Med 1982;306:761.

16 MacFarlane JT, Smith FD, Finch RG. Vidarabine in fulminating chickenpox pneumonia. Thorax 1982;흠 37:226-7.

17 Pillans P. Chickenpox pneumonia. $S$ Afr Med $J \vec{\Phi}$ 1983;63:861-2.

18 Ellis ME, Neal KR, Webb AK. Is smoking a risk factorôs for pneumonia in adults with chickenpox? $\mathrm{Br} M e d \quad \vec{\circ}$ 1987;294:1002.

19 Balfour HH. Intravenous acyclovir therapy for varicella $\vec{\omega}$ in immunocompromised children. J Pediatr 1984; 104:134-6.

20 Shulman ST. Acyclovir treatment of disseminated varicella in childhood malignant neoplasms. Am J Dis. Child 1985;139:137-40.

21 Lankford J, Orr ER, Nitschke R, Humphery GB. A case N of varicella pneumonia treated with transfer factor. $\mathrm{O}$ JAMA 1979;241:2598.

22 Montgomery RR, Olafsson M. Waterhouse-FriderichsenSyndrome in varicella. Ann Intern Med 1960;53:576.

23 Joseph CA, Noah ND. Epidemiology of chickenpox in England and Wales, 1967-85. Br Med J 1988;296: 673-6.

24 Ross AH. Modification of chicken pox in family contacts administration of gamma globulin. $N$ Engl $J$ Med $^{\circ}$ 1962;267:369-76.

25 Winsnes R. Efficacy of zoster immunoglobin in pro-phylaxis of varicella in high risk patients. Acta Paediatr Scand 1978;67:77-82.

26 Foung SK, Perkins S, Koropchak C, et al. Human monoclonal antibodies neutralizing varicella-zoster virus. J Infect Dis 1985;152:280-5.

27 Takahashi M, Otsuka T, Okuno V, et al. Live vaccine used to prevent the spread of varicella in children in hospital. Lancet 1974;ii:1288-90.

28 Sabin AB. Varicella-zoster virus vaccine. JAMA 1977;238:1731-3.

29 Brunell PA. Varicella-zoster virus vaccine. JAMA 1978;239:1034-5.

30 Gershon AA. Live attenuated varicella vaccine. $J$ Infece Dis 1985;152:859-62.

31 Rose RM, Wasserman AS, Weiser Wy, Reinhold HG. Deficient responses of pulmonary macrophages from healthy smokers to antiviral lymphokines in vitro. $J$ Infect Dis 1986;154:611-8.

32 Bocles JS, Ehrenkranz NJ, Marks A. Abnormalities in respiratory function in varicella pneumonia. Ann Intern Med 1964;60:183-95. 